\title{
Antibacterial and antifungal activities of the ethanol extract of some medicinal plants
}

\author{
Nhu Ngoc Nguyen ${ }^{1^{*}}$, Nguyet Minh Vu Thi ${ }^{2}$ \\ Tuyen Phung Thi ${ }^{1}$, Huong Lan Nguyen Thi ${ }^{1}$ \\ ${ }^{1}$ Vietnam National University of Forestry, Hanoi, Vietnam \\ ${ }^{2}$ National Institute of Drug Quality Control, Hanoi, Vietnam
}

(Received: 01/11/2020; Accepted: 17/12/2020)

\section{Abstract}

The aim of this study was to identify and evaluate for antimicrobial activity and phytochemical properties of the extracts from some plants belonging to different species such as Piper betle L., Allium cepa L., Allium ascalonium L., Allium Sativum L., Curcuma longa L., Paederia tomentosa L., Wedelia chinensis M. and Chromolaena odorata L. These extracts have been prepared and the antimicrobial activities have been examined on some bacteria strains like Escherichia coli $\mathrm{T}_{1}$, Bacillus cereus $\mathrm{M}_{1}$, Salmonella sp. ST, Shigella sp. AT and one fungus strain Aspegillus flavus KN by agar disc diffusion method. Results showed that the extracts from total of eight plant species have been inhibited the growth of all over the microorganisms strains used in the test at a different ratio, but the ethanol extracts from Piper betle and Wedelia chinensis M. showed the highest effect. Also, the extracts then were tested for the presence of bioactive compounds. The results showed that there were tannins, flavones, carbohydrates, proteins, and oils in Wedelia chinensis M. extracts. In Piper betle extracts there were many phytochemical compounds including phenols, tannins, saponins, carbohydrates, proteins, resins, and oils.

Keywords: Antimicrobial, extract, herbal medicine Piper betle L., Wedelia chinensis M.

\section{INTRODUCTION}

In recent years, an increasing number of pathogenic organisms are resistant to one or more antimicrobial drugs. As a consequence, some common infections have become extremely difficult and, in some cases, need quite always more complex antibiotic treatments that impose additional costs on the patients and the health system or nearly impossible to treat.

Faced with this reality, scientists have forced to search for new antimicrobial substances from various sources like herbal medicine. Search for new antibacterial agents should be continued by screening many plant families. Recent work revealed the potential of several herbs as sources of drugs, for example, spices are partly used to counter food spoilage microorganism (bacteria), especially in hot climates [1], and especially in meat dishes that spoil more readily [2], most of the extracts including sugar alcohols do not contribute to tooth day [3]. Angiosperms (flowering plants) were known to be the source of many plant medicines. Human settlements are usually surrounded by weeds often used as herbal medicines, such as dandelion, chickweed, and nettle [4].

This study has been conducted to find out the medicinal properties like antimicrobial of 
the extracts from locally available herbal medicines against foodborne pathogens. The use of crude extracts of plant parts and phytochemicals, of known antimicrobial properties, can be of great significance in the treatments.

\section{MATERIALS AND METHODS}

\subsection{Materials}

The herbal medicines selected for the study were from the local area (Luot mountain Xuan Mai - Chuong My - Ha Noi) based on their basic information available [5]. The plants are Piper betle L., Allium cepa L., Allium ascalonium L., Allium Sativum L., Curcuma longa L., Paederia Tomentosa L., Wedelia chinensis M. and Chromolaena odorata L.. All the fresh samples of the plant were collected, washed, and removed the excess water and then stored in the fridge to use for further studies.

Some food-borne pathogen strains such as bacteria including Escherichia coli $\mathrm{T}_{1}$, Bacillus cereus $\mathrm{M}_{1}$; Salmonella sp. ST; Shigella sp. AT and fungi Aspergillus flavus $\mathrm{KN}$ were obtained from the Laboratory of The College of Forestry Biotechnology - The Vietnam National University of Forestry.

\subsection{Methods}

\subsubsection{Preparation of plant extracts}

The collected plant materials in the fresh form were weighed to $50 \mathrm{~g}$ of each sample and then some of them remained fresh and others were air-dried. Both fresh and dried samples were powdered and then were extracted with ethanol $70 \%(500 \mathrm{~mL})$ by using a cold extraction method on a rotary shaker $(100 \mathrm{rpm})$ for three days. After three days of extraction, the extracts were filtered using Whatman filter paper (No1), and then the solvent was evaporated from the extracts by using a rotary evaporator at $37^{\circ} \mathrm{C}$. The concentrated extracts were stored at $4^{\circ} \mathrm{C}$ and used for the determination of their antimicrobial activity.

\subsubsection{Antimicrobial activity}

The concentrated extracts were dissolved again in ethanol (35\%) to obtain a concentration of $100 \mathrm{mg} / \mathrm{mL}$. The ethanol extracts of eight plants were subjected to antibacterial evaluation against four bacterial strains: Escherichia coli $\mathrm{T}_{1}$, Bacillus cereus $\mathrm{M}_{1}$, Salmonella sp. ST, Shigella sp. AT and fungi Aspergillus flavus KN, using agar well diffusion method as described by Mounyr B. [6].

All of the tested bacteria and fungi were activated and ingrown nutrient broth (NB) for bacteria and PDA (potatose dextrose agar) for fungi for 24 hours, followed by the matching of a bacterial suspension at the density of $10^{8} \mathrm{CFU} / \mathrm{mL}$ and fungi suspension at the density of $10^{8}$ spores $/ \mathrm{mL}$. Next, the $20 \mathrm{~mL}$ of sterilized nutrient agar (NA) or PDA media was poured into sterile petri plates, after solidification, $100 \mu \mathrm{L}$ of fresh culture of foodborne pathogens and fungi spores suspension were swabbed on the respective plates, respectively. The wells were punched over the agar plates using a sterile gel puncher with $8 \mathrm{~mm}$ of diameter and then $50 \mu \mathrm{L}$ each of the ethanol extracts was added to the wells at various concentrations ( 200 and $300 \mu \mathrm{g} / \mathrm{mL}$ ). The agar discs were incubated at $37^{\circ} \mathrm{C}$ for 24 hours for bacteria test and 72 hours for fungi test. At the same time, discs injected with ethanol 35\% served as negative control and cefotaxime at 10 $\mu \mathrm{g} / \mathrm{mL}$ as a positive control. After incubation, the diameter of inhibitory zones formed around 
each well was measured in $\mathrm{mm}$ and recorded. The readings were taken in three different fixed directions in all three replicates and the average value was tabulated.

\subsubsection{Effect of extraction solvent}

Four sources of solvent with different polarities including acetone 70\%; ethyl acetate 70\%; ethanol 70\% and water were used to extract and test the antagonistic activity of the material.

\subsubsection{Determination of the presence of phytochemical compounds}

To determine the presence of phytochemical compounds such as flavones, tannins, phenol, saponines, glycosides, alkaloids in crude extract, the test was done according to methods of Zeinab Abbas S. A. [7]. The experiments were performed as described below:

Flavones test: A-quantity of $10 \mathrm{~g}$ of the powdered explants was macerated in $95 \%$ ethanol than filtered with filter paper (what man no.1). B-aliquot of $10 \mathrm{~mL}$ of $50 \%$ ethanol was added to $10 \mathrm{~mL}$ of $50 \%$ aqueous $\mathrm{KOH}$ the solution was mixed with solution B appearance of yellow color indicated a positive result.

Tannins test: Two milliliters of plant extract sample after filtration were added to $1 \%$ of lead acetate, the appearance of the precipitant gel was indicated to a positive result.

Phenol compound test: Two milliliters of plant extract after filtration were added to $1 \%$ of ferric chloride, the appearance of dark blue color was indicated to the presence of phenol compound.

Saponines test: One milliliter of mercuric chloride (1\%) was added to $2 \mathrm{~mL}$ of plant extract after filtration the observation of white precipitate was indicated to a positive result.

Glycosides test: By addition of few drops from Kedde reagent to $3 \mathrm{~mL}$ of plant extract after filtration. The appearance of blue-purple color is indicated to a positive result.

Alkaloids test: A few drops of modified Dragendroffs reagent to $5 \mathrm{~mL}$ of plant extract after filtration. The appearance of reddish-orange color is indicated to a positive result.

All experiments were repeated three times in statistically analyzed.

\section{RESULTS AND DISCUSSION}

\subsection{Antibacterial activity of Piper betle $L$. and Wedelia chinensis M. extracts}

The antimicrobial potential of plants was compared according to their zone of inhibition against several pathogenic organisms. All the herbal medicine extracts used against the pathogenic organisms have shown a varied degree of antimicrobial activity against the pathogens.

The ethanol extract of Piper betle L. and Wedelia chinensis M. showed high antimicrobial activity against all four selected pathogenic bacteria (Escherichia coli $\mathrm{T}_{1}$, Bacillus cereus $\mathrm{M}_{1}$, Salmonella sp. ST, Shigella sp. AT) as exhibited by disc diffusion method (Table 1). 
Table 1. Antibacterial activity of ethanol extracts of several herbal medicine species

\begin{tabular}{|c|c|c|c|c|}
\hline \multirow{2}{*}{$\begin{array}{l}\text { Plant extract } \\
(300 \mu \mathrm{g} / \mathrm{mL})\end{array}$} & \multicolumn{4}{|c|}{ Zone of Inhibition (mm) } \\
\hline & Salmonella sp. ST & E. coli $T_{1}$ & Shigella sp. AT & B. cereus $M_{1}$ \\
\hline Chromolaena odorata $\mathrm{L}$. & $11.5 \pm 0.05$ & $11.0 \pm 0.04$ & $10.8 \pm 0.03$ & - \\
\hline Allium ascalonicum L. & $7.5 \pm 0.03$ & $8.3 \pm 0.04$ & - & - \\
\hline Allium cepa $\mathrm{L}$. & $10.5 \pm 0.03$ & $10.8 \pm 0.04$ & - & - \\
\hline Paederia tomentosa $\mathrm{L}$. & $11.0 \pm 0.02$ & - & $10.4 \pm 0.03$ & - \\
\hline Piper betle $\mathrm{L}$. & $16.8 \pm 0.05$ & $17.2 \pm 0.04$ & $16.9 \pm 0.05$ & $17.4 \pm 0.04$ \\
\hline Curcuma longa $\mathrm{L}$. & $10.3 \pm 0.03$ & - & - & $11.2 \pm 0.04$ \\
\hline Wedelia chinensis $\mathrm{M}$. & $18.8 \pm 0.04$ & $\mathbf{1 7 . 5} \pm 0.05$ & $16.7 \pm 0.04$ & $14.6 \pm 0.05$ \\
\hline Allium sativum $\mathrm{L}$. & $8.7 \pm 0.03$ & $12.0 \pm 0.04$ & $11.2 \pm 0.05$ & $10.6 \pm 0.04$ \\
\hline $\begin{array}{l}\text { Cefotaxime } 10 \mu \mathrm{g} / \mathrm{mL} \\
\text { (positive control) }\end{array}$ & $20.4 \pm 0.04$ & $21.2 \pm 0.05$ & $19.7 \pm 0.04$ & $20.8 \pm 0.05$ \\
\hline
\end{tabular}

"-": Not detected

The antimicrobial activity of different plant extracts is changeable according to the other researcher findings [8-9] which may arise from the genetic structure of plant species and physical, bioactive biochemical constituents and chemical differences of plant extract, solvent, and test microorganisms. For instance, Selvamohan T. reported that the ethanol extract of Aloe vera has antibacterial activity against E. coli $(21 \mathrm{~mm})$ [10]. P1nar E. also showed that the extract of $P$. terebinthus subsp. palestina has activity against $C$. tropicalis $(24 \mathrm{~mm})$, Trichophyton $\mathrm{sp}$, B. megaterium, S. aureus, E. coli [11]. According to Sana M.'s report [12], the extract of Allium sativum L. also showed antibacterial activity against streptomycin-resistant $E$. coli strain.

The results in this study indicated that the antimicrobial activity of ethanol extracts of Piper betle L. and Wedelia chinensis M. on four different human pathogenic organisms using the disc diffusion method have shown maximum zone of inhibition up to 16.8 and $18.8 \mathrm{~mm}$ (Table 1) against Salmonella sp, followed by E. coli (17.2 and $17.5 \mathrm{~mm})$, Shigella sp. (16.7 and $16.9 \mathrm{~mm}$ ) and B. cereus (14.6 and $17.4 \mathrm{~mm})$. Therefore, we decided to choose these two species for further research.

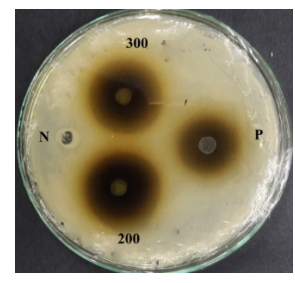

1 Salmonella sp.

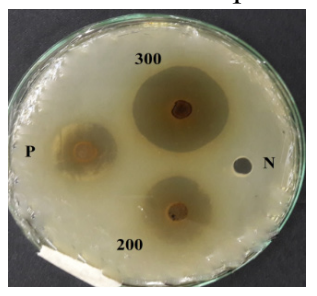

2 Salmonella sp.

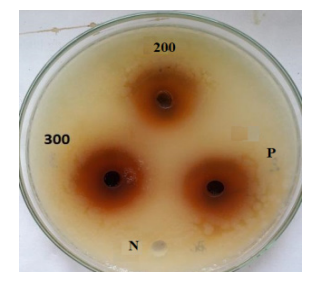

E. coli

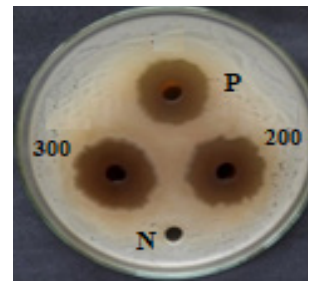

E. coli

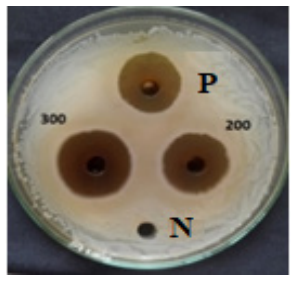

Shigella sp.

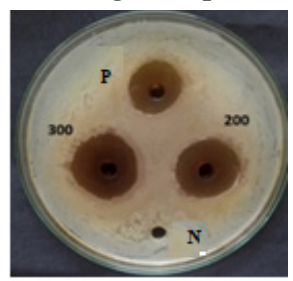

Shigella sp.

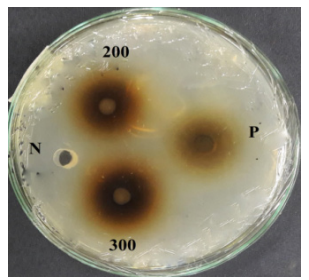

B. cereus

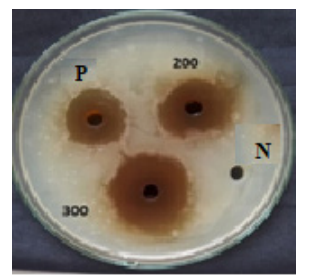

P: positive control $\mathrm{N}$ : Negative control 300: $300 \mu \mathrm{g} / \mathrm{mL}$ 200: $200 \mu \mathrm{g} / \mathrm{mL}$

B. cereus

Figure 1. Diameter of inhibition zone of Piper betle L. (1) and Wedelia chinensis M.

(2) extracts against tested bacteria 


\subsection{Antifungal activity of Piper betle L. and Wedelia chinensis M.extracts}

Antifungal activity of Piper betle L. and Wedelia chinensis M. extract were tested and recorded based on the inhibition of the growth of Aspergillus flavus mycelia. The average diameter of the inhibition zone of fungal mycelia was measured after three and seven days of incubation. The results showed in Table 2, Figure 2 and Figure 3.

Table 2. Diameter of inhibition zone of Aspergillus flavus KN mycelia ( $\mathrm{mm}$ )

\begin{tabular}{|c|c|c|c|c|}
\hline \multirow[b]{2}{*}{ Extracts } & \multirow{2}{*}{$\begin{array}{c}\text { Solvent } \\
(\%)\end{array}$} & \multirow{2}{*}{$\begin{array}{c}\text { Ratio materia } \\
\text { on Solvent } \\
(g / m L)\end{array}$} & \multicolumn{2}{|c|}{ Diameter of inhibition zone ( $\mathrm{mm})$} \\
\hline & & & $\begin{array}{c}300 \mu g / m L \\
\text { extract }\end{array}$ & $\begin{array}{l}\text { Cefotaxime } \\
10 \mu \mathrm{g} / \mathrm{mL}\end{array}$ \\
\hline Fresh Piper betle L. & EtOH 70\% & $1: 10$ & $21.5 \pm 0.87$ & $14.5 \pm 0.52$ \\
\hline Dried Piper betle L. & $\mathrm{EtOH} 70 \%$ & $1: 10$ & $20.75 \pm 0.93$ & - \\
\hline Fresh Wedelia chinensis M. & EtOH 35\% & $1: 10$ & $19.5 \pm 0.17$ & - \\
\hline Dried Wedelia chinensis M. & EtOH $70 \%$ & $1: 10$ & $20 \pm 0.93$ & - \\
\hline
\end{tabular}

"-": Not detected

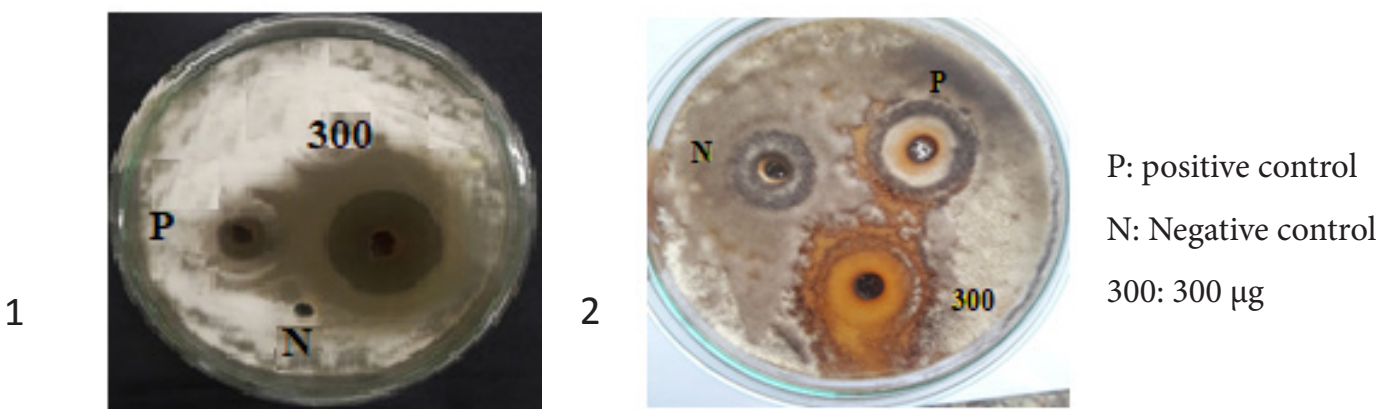

Figure 2. Diameter of inhibition zone of Aspergillus flavus KN mycelia of Piper betle L. extract after 3 (1) and 7 (2) days

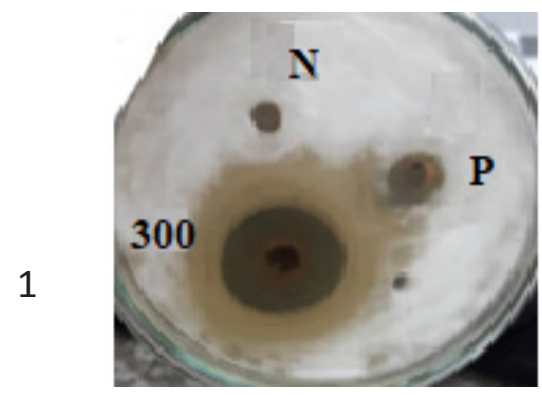

2

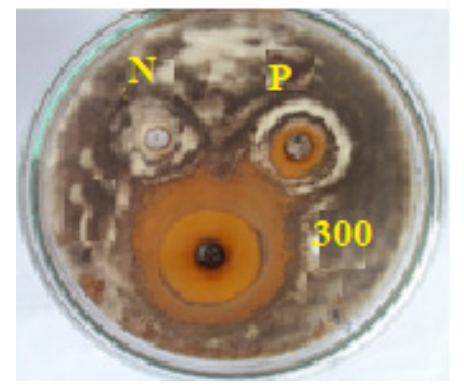

Figure 3. Diameter of inhibition zone of Aspergillus flavus KN mycelia of Wedelia chinensis M. extract after 3 (1) and 7 (2) days

From Table 2, both Piper betle L. and Wedelia chinensis M. extract showed a significant reduction in the growth of the test pathogens. The results showed that the ethanol extract of Piper betle L. in both fresh and dried form has exhibited good antifungal activity against A. flavus. 
The antifungal efficiency of extracts of fresh form was higher than a dried form with a diameter of inhibition zone up to $21.5 \pm 0.87 \mathrm{~mm}$ at the concentration of $300 \mu \mathrm{g} / \mathrm{mL}$. The results were similar to the extracts from Wedelia chinensis $\mathrm{M}$. in fresh and dried form. The antifungal activity was exhibited clearly with the diameter of the inhibition zone of $A$. flavus $\mathrm{KN}$ mycelia growth up to $17-20 \mathrm{~mm}$ at the extract concentration of $300 \mu \mathrm{g} / \mathrm{mL}$. The comparison of the antifungal activity of the extracts from Piper betle L. and Wedelia chinensis M. to antifungal efficiency of positive control treated with Cefotaxime $10 \mu \mathrm{g} / \mathrm{mL}$ indicated that the efficiency of the extracts form herbal medicine were higher than that of antibiotic at low concentration.

The results in this study suggest that those extracts may possess some of the compounds with antibacterial and antifungal properties that can be used as antimicrobial agents in the development of new drugs for the treatment of infectious diseases.

\subsection{The influence of Solvent on antagonistic efficiency}

The successive isolation of botanical compounds from plant material is largely dependent on the type of solvent used in the extraction procedure. In this study, four different sources of solvent including acetone $70 \%$; ethyl acetate $70 \%$; ethanol 70\%, and water were used to extract antibacterial and antifungal compounds from Piper betle L. and Wedelia chinensis M. and determine the antagonistic efficiency of the extracts. The traditional healers use primarily water as the solvent but we found in this study the plant extracts by ethanol provided more consistent antimicrobial activity compared to those extracted by others. The results of antibacterial activity extracted from Piper betle L. and Wedelia chinensis M. against the investigated bacterial strains in Table 3 and Table 4 showed that ethanol was exhibited to be the most efficient solvent. The diameter of the inhibition zone was up to $17.75-25.5 \mathrm{~mm}$ of Piper betle L. extract and $16.3-19.4$ $\mathrm{mm}$ of Wedelia chinensis $\mathrm{M}$. at the concentrations of $300 \mu \mathrm{g} / \mathrm{mL}$ while that of the extract with other solvents were much lower. This might have resulted from the lack of solubility of the active constituents in aqueous solutions and other solvents while ethanol extract showed some degree of antibacterial activity.

Table 3. Diameter of inhibition zone of Piper betle L. extract against pathogens based on solvents $(\mathrm{mm})$

$\begin{array}{cccccc}\text { Extract } & \text { Salmonellasp. } & \text { E.coli } T_{1} & \text { Shigellasp. AT } & \text { B.cereus } M_{1} \\ \text { Solvents } & (\mu \mathrm{g} / \mathrm{mL}) & S T & & \end{array}$

\begin{tabular}{llllll}
\hline Acetone $70 \%$ & 300 & $17.5 \pm 0.87$ & $17 \pm 0.85$ & $20 \pm 0.97$ & $18.5 \pm 0.92$
\end{tabular}

Ethanol 70\%

Ethyl acetate $70 \%$

300

300

$20.5 \pm 1.02$

$19.5 \pm 0.97$

$17.75 \pm 0.88$

$25.5 \pm 1.27$

Water

300

$16.5 \pm 0.82$

$16.5 \pm 0.8$

$13.5 \pm 0.67$

$18.5 \pm 0.93$ 
Table 4. Diameter of inhibition zone of Wedelia chinensis M. extract against pathogens based on solvents $(\mathrm{mm})$

\begin{tabular}{|c|c|c|c|c|c|}
\hline Solvents & $\begin{array}{c}\text { Extract } \\
\text { Concentration } \\
(\mu g / m L)\end{array}$ & $\begin{array}{c}\text { Salmonella sp. } \\
\text { ST }\end{array}$ & E. $\operatorname{coli} T_{1}$ & $\begin{array}{c}\text { Shigella sp. } \\
A T\end{array}$ & B. cereus $M_{1}$ \\
\hline Acetone $70 \%$ & 300 & - & - & $4 \pm 0.2$ & - \\
\hline \multirow[t]{2}{*}{ Ethanol 70\% } & 300 & $16.5 \pm 0.32$ & $18.5 \pm 0.42$ & $16.3 \pm 0.33$ & $19.4 \pm 0.45$ \\
\hline & 300 & $4.25 \pm 0.21$ & $4.5 \pm 0.22$ & - & $7.5 \pm 0.3$ \\
\hline \multirow{2}{*}{ Ethyl acetate $70 \%$} & 200 & $3 \pm 0.15$ & $3.25 \pm 0.16$ & - & $5 \pm 0.22$ \\
\hline & 100 & - & $1.5 \pm 0.07$ & - & - \\
\hline Water & 300 & - & - & - & - \\
\hline
\end{tabular}

"-": Not detected

In recent studies, it has been reported that the methanol and ethanol extracts of Piper betle L. could inhibit both Gram-positive and negative and E. coli $[11,13]$.

\subsection{The characterization of phytochemical compounds in crude extracts}

About the characterization of phytochemical compound of extracts from Piper betle L. and Wedelia chinensis M. It was found that there were different compounds like flavones, phenols, tannins, saponines, oils, proteins, carbohydrates, alkaloids, resins in crude extracts. This result showed in Table 5 which agreed with the report of Ionela D. C. [14].

Table 5. The characterization of phytochemical compound

\begin{tabular}{lcccc}
\hline & & & \multicolumn{2}{c}{ Results } \\
\cline { 4 - 5 } No & Test & Color Regent & Piper betle L. & Wedelia chinensis M. \\
\cline { 3 - 4 } & & Yellow & - & + \\
2 & Flavones & Blue color & + & + \\
3 & Thenol & Gel precipitate & + & + \\
4 & Saponines & White precipitate & + & + \\
5 & Cacbohydrates & Yellow precipitate & + & + \\
6 & Proteins & Blue color & + & + \\
7 & Resins & Turbidity & + & + \\
8 & Oil & Pinkish & + & + \\
\hline
\end{tabular}

Positive: (+); Negative: (-) 


\section{CONCLUSION}

It can be concluded that most fraction of herbal medicine Piper betle L., Allium cepa L., Allium ascalonium L., Allium Sativum L., Curcuma longa L., Paederia Tomentosa L., Wedelia chinensis M. and Chromolaena odorata L. showed potential antimicrobial activities against the tested bacterial and one fungal strain. The best solvent which could be extracted the antimicrobial activities was ethanol and the characterization of phytochemical compounds in the crude extract showed there were flavones, phenols, tannins, saponines, oils, proteins, carbohydrates, alkaloids, resins. Results of our findings confirmed the use of Piper betle L. and Wedelia chinensis M. as traditional medicine. However, these herbal medicine species may be subjected to detailed phytochemical studies in order to find out the new application of these herbal medicine species against pathogenic bacterial and fungal strains.

\section{REFERENCES}

[1]. C. Tapsell, I. Hemphill, and L. Cobiac, "Health benefits of herbs and spices: the past, the present, the future", Medical Journal of Australia, vol. 185, no. 4, pp. 4-24, 2006.

[2[. W. Sherman and A. Hash, "Why vegetable recipes are not very spicy", Evolution and Human Behavior, vol. 22, no. 3, pp. 147-163, 2001.

[3[. C. Awuchi, "Sugar Alcohols: Chemistry, Production, Health Concerns and Nutritional Importance of Mannitol, Sorbitol, Xylitol, and Erythritol", International Journal of Advanced Academic Research, vol. 3, no. 2, pp. 31- 66, 2017.

[4[. R. Stepp and R. John, “The role of weeds as sources of pharmaceuticals", Journal of Ethnopharmacology, vol. 92, no. 3, pp. 163-166, 2004.

[5]. D. T. Loi, Vietnamese medicinal plants and medicinal herbs. Hanoi: Medical Publishing house, 2006.

[6]. M. Balouiri, M. Sadiki and S. Ibnsouda, "Methods for in vitro evaluating antimicrobial activity: A review", Journal of Pharmaceutical Analysis, vol. 6, pp. 71-79, 2016.

[7]. Z. Al-Saeedi, Extraction and partial purrification of wedelolactone from Eclipta alba plant and study Bioactivity on mice. Baghdad: B.Sc. Biotechnology, 2013.

[8]. B. Özçelik, M. Aslan, I Orhan and T. Karaoğlu, "Antibacterial, Antifungal and Antiviral Activities of the Lipophylic extracts of Pistacia vera", Microbiological Research, vol. 160, pp. 159- 164, 2005.

[9]. R. Govindarajan, M. Vijayakumar, M. Singh. and P. Pushpangadan, "Antiulcer and Antimicrobial Activitiy of Anogiesus latifolia”, Journal of Ethnopharmacology, vol 106, pp. 57-61, 2006.

[10]. T. Selvamohan, V. Ramadas and S. Shibila, "Antimicrobial activity of selected herbal medicine against some selected human pathogenic bacteria", Advances in Applied Science Research, vol. 3, no. 5, pp. 3374-3381, 2012.

[11]. P. Erecevit and S. Kirbağ, "Antimicrobial activity of some plant species used for the medical purpose in Turkey", The Journal of Phytopharmacology, vol. 6, no. 2, pp. 93-97, 2017.

[12]. M. Sana and G. Ifra, "Antibacterial activity of aqueous and ethanol extracts of garlic, 
cinnamon and turmeric against Escherichia coli ATCC 25922 and bacillus subtilis DMS 3256", International Journal of Applied Biology and Pharmaceutical Technology, vol. 3, no. 2, pp. 131-136, 2012.

[13]. H. Sakha, R. Hora, S. Shrestha ... and K. Prajapati, "Antimicrobial Activity of Ethanol extract of Medicinal Plants against Human Pathogenic Bacteria", Tribhuvan University Journal of Microbiology, vol. 5, no. 1, pp. 1-6, 2018.

[14]. D. Ciocan, "Bawrra Plant products as antimicrobial agents", Tom VIII, pp. 151-156, 2007.

\title{
Hoạt tính kháng khuẩn và kháng nấm của cao chiết ethanol một số loài thảo dược
}

\author{
Nguyễn Nhui Ngọc ${ }^{1^{*}}$, Vũ Thị Nguyệt Minh ${ }^{2}$ \\ Phùng Thị Tuyến ${ }^{1}$, Nguyễn Thị Hương Lan ${ }^{1}$ \\ ${ }^{1} Đ a ̣ i$ học Lâm Nghiệp Việt Nam, Hà Nội, Việt Nam \\ ${ }^{2}$ Viện Kiểm nghiệm thuốc Trung ương, Hà Nội, Việt Nam
}

\section{Tóm tắt}

Mục tiêu của nghiên cứu này nhằm xác định và đánh giá hoạt tính kháng khuẩn, kháng nấm và xác định sự có mặt của một số hợp chất có hoạt tính trong cao chiết của một số loài cây dược liệu như Trầu không (Piper betle L.), Hành tây (Allium cepa L.), Hành tím (Allium ascalonium L.), Tỏi (Allium sativum L.), Nghệ (Curcuma longa L.), Lá mơ (Paederia Tomentosa L.), Sài đất (Wedelia chinensis M..) và Cỏ hôi (Chromolaena odorata L.). Cao chiết ethanol từ mẫu của các loài thảo dược này đã được xác định khả năng kháng với một số chủng vi khuẩn như: Escherichia coli $\mathrm{T}_{1}$, Bacillus cereus $\mathrm{M}_{1}$, Salmonella sp. ST, Shigella sp. AT và một chủng nấm Aspegillus flavus KN bằng phương pháp khuếch tán đĩa thạch. Kết quả cho thấy cao chiết ethanol từ cả tám loài thảo dược đêu thể hiện ức chế sự phát triển của tất cả các chủng vi sinh vật thử nghiệm ở các mức khác nhau. Cao chiết từ trầu không và sài đất cho thấy hiệu quả kháng vi sinh vật cao nhất. Kết quả định tính sự có mặt của các hợp chất thứ cấp có hoạt tính kháng khuẩn cho thấy: Với mẫu sài đất, cao chiết có chứa các hợp chất: tannin, flavon, cacbohydrat, protein và tinh dầu. Trong cao chiết từ trầu không, các hợp chất bao gồm phenol, tannin, saponin, cacbohydrat, protein, nhựa và tinh dầu.

Tư khóa: Cây thuốc, chiết xuất, kháng khuân, sài đất, trầu không. 